\title{
Spatio-temporal distribution of Erysiphe necator genetic groups and their relationship with disease levels in vineyards
}

\author{
Josselin Montarry $•$ Philippe Cartolaro • \\ Sylvie Richard-Cervera • François Delmotte
}

Received: 22 February 2008 / Accepted: 29 May 2008

(C) KNPV 2008

\begin{abstract}
The discovery of genetically distinct Erysiphe necator groups (A or $\mathrm{B})$, with high phenotypic similarities, raises important questions about their coexistence. For plant pathogens, niche partitioning, allowing the coexistence on the same host (i.e. the same resource), might result from separation in space and/or time. We used a landscape genetic approach to study the geographic distribution of genetic groups of E. necator (distinguished by a SNP in the $\beta$-tubulin gene) at the spatial scale of the Languedoc-Roussillon region (southern France) and to assess the temporal succession of groups along the course of the 2007 epidemic. Spatial distribution revealed a high heterogeneity between vineyards: from $100 \%$ B to $100 \%$ A, with $62 \%$ and $38 \%$ of vineyards showing a majority of $\mathrm{A}$ and $\mathrm{B}$ isolates, respectively. Temporal isolation seems to be the major mechanism in the coexistence of the two genetic groups: all isolates collected towards the end of the epidemic belonged to group B, whatever the initial frequency of genetic groups. Our results confirm that both A or B isolates can lead to flag-shoot symptoms, and showed that group $\mathrm{A}$ isolates tend to disappear during the course of the epidemic, whereas group $\mathrm{B}$ isolates may be active during the entire
\end{abstract}

J. Montarry $(\bowtie) \cdot$ P. Cartolaro $\cdot$ S. Richard-Cervera $\cdot$

F. Delmotte

INRA, Institut des Sciences de la Vigne et Vin de

Bordeaux, UMR1065 Santé Végétale (INRA-ENITAB),

F-33883 Villenave d'Ornon, France

e-mail: Josselin.Montarry@bordeaux.inra.fr epidemic and involved in further production of cleistothecia, when recombination takes place. For the first time, the relationship between the frequency of genetic groups and disease levels on leaves and clusters at the end of the epidemic was evaluated. We showed a strong relationship between the disease severity and the genetic composition of E. necator populations: the damage was more important when the epidemic was initiated by $\mathrm{B}$ isolates.

Keywords Coexistence Cryptic species .

Grapevine powdery mildew $\cdot$ Landscape

epidemiology $\cdot$ Plant pathogen $\cdot$ Vitis vinifera

\section{Introduction}

A growing number of genetic studies of plant pathogens demonstrate that species harbour hidden genetical diversity in the form of cryptic species. There are now several well documented examples of plant pathogen species, such as Leptosphaeria maculans (Williams and Fitt 1999), Gaeumannomyces graminis var. tritici (Lebreton et al. 2004), Botrytis cinerea (Fournier et al. 2005) and Erysiphe syringae (Seko et al. 2008), which are indeed composed of genetically differentiated clades that have led to the description of new groups or even new species. The discovery of genetically differentiated sibling species, with high phenotypic similarities, raises important questions about their coexistence. Since the competi- 
tion theory states that two species occupying the same ecological niche cannot coexist indefinitely (Gausse 1934; Chesson 2000), sibling plant pathogen species might coexist on the same host through niche partitioning despite their high phenotypic similarity. Ecological differences that lead to niche partitioning can occur in three basic ways: resource partitioning, temporal niche partitioning, and spatial niche partitioning (Wilson and Lindow 1994; Chesson 2000; Amarasekare 2003). For plant pathogenic species coexisting on the same host, i.e. the same resource, the separation in space and/or time might better explain niche partitioning (e.g. Fitt et al. 2006).

Grapevine powdery mildew, caused by the biotrophic ascomycete Erysiphe necator (syn. Uncinula necator), is one example of a plant pathogen showing two genetically differentiated groups of isolates coexisting on the same host, Vitis vinifera (Délye et al. 1997; Evans et al. 1997; Miazzi et al. 2003; Nuñez et al. 2006). Several studies have suggested that genetic E. necator groups (A and B) correlated with ecological features of the pathogen; Délye et al. (1997) proposed that group A isolates over-winter as resting mycelium within dormant buds that reinitiate growth after budbreak and colonise young flag-shoots (Pearson and Gärtel 1985), while group B isolates would survive as ascospores released from overwintering cleistothecia (Gadoury and Pearson 1988). Indeed, an association between flag-shoot symptoms and infection by group A isolates has been found in earlier studies in France (Délye and Corio-Costet 1998; Amrani and Corio-Costet 2006) and Italy (Miazzi et al. 2003). Due to this association, these authors proposed that group A isolates may be responsible for early infections in the season while group B isolates may be responsible for late infections (Délye and Corio-Costet 1998; Miazzi et al. 2003). However, the association between genetic groups and over-wintering survival has been challenged by recent studies reporting that flag-shoot symptoms may harbour both group $\mathrm{A}$ and $\mathrm{B}$ isolates (Cortesi et al. 2005; Nuñez et al. 2006; Péros et al. 2005; Willocquet et al. 2007). Moreover, the hypothesis of a temporal succession of genetic groups was based on genetic studies that suffered from sampling strategies confounding time during the epidemic with over-wintering mode and source of inoculum.

Geographical distribution that could lead to spatial niche differentiation of the E. necator genetic groups has always been addressed on a small number of populations, impeding tests for spatial structure. Data available showed that the frequencies of the groups could vary greatly from one field to another, suggesting a high level of spatial heterogeneity at the vineyard scale (Cortesi et al. 2005; Amrani and Corio-Costet 2006; Bouscaut and Corio-Costet 2007; Willocquet et al. 2007).

Here, our aim is to study the regional dynamics of E. necator genetic groups at a large spatial scale. This work is part of the recent development using genetic tools to study the influence of habitat heterogeneity in space and time on plant pathogen epidemics (e.g. Plantegenest et al. 2007). We conducted a landscape genetic approach combining landscape epidemiology and population genetics (Manel et al. 2003) in order to explore the geographic distribution of E. necator genetic groups in southern France vineyards, and to assess the temporal succession of groups along the course of the epidemics. Moreover, we have evaluated the relationship between the frequency of genetic groups and disease level on leaves and clusters at the end of the epidemics. This study therefore addressed three questions: (1) what is the genetic variability (A or B) of E. necator populations on flag-shoots at a regional scale? (2) are there changes in the frequency of genetic groups between the start and the end of the epidemic? and, (3) is there a relationship between the frequency of genetic groups assessed early in the season and disease levels at the end of the growing season?

\section{Materials and methods}

Isolate collection

Diseased leaves of cv. Carignan (Vitis vinifera) were randomly sampled twice during the 2007 growing season in commercial vineyards of the LanguedocRoussillon region. The first sampling was performed in 32 vineyards early in the growing season (end of April) and the second sampling in 16 of those 32 vineyards at the end of the growing season (early September). At the first sampling, diseased leaves were collected only on flag-shoots; at the second sampling, diseased leaves were randomly collected within each vineyard. Depending on the disease pressure, up to 40 leaves were collected per vineyard. 
This led to a total of 1,253 leaves infected with $E$. necator, of which 769 were sampled in April and 484 in September. On each leaf, a $1 \mathrm{~cm}$ diam disc was taken out with a punch and frozen for DNA extraction. The location of each vineyard was recorded using GPS (Table 1).

\section{Molecular characterisation}

The molecular method used to differentiate genetic groups was the amplification of the $\beta$-tubulin gene of E. necator (tub2, accession number AY074934)

Table 1 GPS position, number of isolates sampled $\left(N_{\mathrm{s}}\right)$, number of isolates yielding a PCR amplicon of the $\beta$-tubulin gene $(N)$ and percentage of group A isolates and group B exhibiting a $\mathrm{T} / \mathrm{C}$ single nucleotide polymorphism (SNP) between group A and group B isolates (Amrani and Corio-Costet 2006). SNP creates a recognition site of restriction endonuclease $A c c$ I that allows the characterisation of A or B isolates by Cleaved Amplified Polymorphic Sequence (CAPS) analysis (e.g. Baudoin et al. 2008).

Total genomic DNA was extracted directly from lesions (infected leaf discs) collected in the vineyards without any prior subculture of the fungus. Lesions were crushed in $400 \mu \mathrm{l}$ CTAB buffer and then heated at $65^{\circ} \mathrm{C}$ for $1 \mathrm{~h} ; 400 \mu \mathrm{l}$ isoamyl alcohol/chloroform

isolates for each of the 32 fields of cv. Carignan at the start of the epidemic, and for 16 out of the 32 fields at the end of the epidemic

\begin{tabular}{|c|c|c|c|c|c|c|c|c|c|}
\hline \multirow[t]{2}{*}{ Fields } & \multirow[t]{2}{*}{ Location } & \multicolumn{4}{|c|}{ Epidemic start (April) } & \multicolumn{4}{|c|}{ Epidemic end (September) } \\
\hline & & $N_{5}$ & $N$ & $\% \mathrm{~A}$ & $\% \mathrm{~B}$ & $N_{5}$ & $N$ & $\% \mathrm{~A}$ & $\% \mathrm{~B}$ \\
\hline AZI & N43 1741.7 E2 3836.3 & 32 & 31 & 87.1 & 12.9 & & & & \\
\hline $\mathrm{BRU}_{1}$ & N43 $08 \begin{array}{llll}13.6 & \text { E2 } & 09 & 07.7\end{array}$ & 21 & 21 & 100.0 & 0.0 & 31 & 26 & 0.0 & 100.0 \\
\hline $\mathrm{BRU}_{2}$ & N43 08 09.6 E2 0908.0 & 25 & 23 & 26.1 & 73.9 & 26 & 5 & 0.0 & 100.0 \\
\hline CAF & N42 $48 \quad 35.9$ E2 2312.3 & 29 & 26 & 0.0 & 100.0 & 30 & 15 & 0.0 & 100.0 \\
\hline CAN & N42 3700.2 E2 5017.7 & 36 & 34 & 44.1 & 55.9 & & & & \\
\hline CAV & N42 5556.3 E2 5916.5 & 27 & 23 & 65.2 & 34.8 & 34 & 11 & 0.0 & 100.0 \\
\hline $\mathrm{CRL}_{1}$ & $\begin{array}{llllll}\text { N43 } & 02 & 13.6 & \text { E2 } & 13 & 44.8\end{array}$ & 14 & 14 & 35.7 & 64.3 & & & & \\
\hline $\mathrm{CRL}_{2}$ & $\begin{array}{llllll}\text { N43 } & 02 & 10.1 & \text { E2 } & 13 & 59.4\end{array}$ & 15 & 15 & 13.3 & 86.7 & & & & \\
\hline ESL & N42 4557.4 E2 4045.1 & 30 & 29 & 65.5 & 34.5 & 31 & 12 & 0.0 & 100.0 \\
\hline FIT & N42 5401.3 E2 5609.0 & 36 & 36 & 100.0 & 0.0 & 12 & 6 & 0.0 & 100.0 \\
\hline $\mathrm{GIN}_{1}$ & N43 1638.1 E2 5156.9 & 28 & 24 & 0.0 & 100.0 & 18 & 5 & 0.0 & 100.0 \\
\hline $\mathrm{GIN}_{2}$ & N43 1638.1 E2 5156.9 & 20 & 13 & 0.0 & 100.0 & & & & \\
\hline $\mathrm{LAM}_{1}$ & N43 1658.1 E2 3228.2 & 32 & 26 & 88.5 & 11.5 & & & & \\
\hline $\mathrm{LAM}_{2}$ & N43 1658.1 E2 3228.2 & 30 & 20 & 75.0 & 25.0 & & & & \\
\hline LAP & N42 5728.2 E2 5909.6 & 31 & 29 & 86.2 & 13.8 & & & & \\
\hline LBO & N42 3250.4 E2 5114.8 & 6 & 6 & 100.0 & 0.0 & & & & \\
\hline $\mathrm{LDA}_{1}$ & N43 $02 \quad 36.9$ E2 1109.2 & 17 & 17 & 47.1 & 52.9 & 33 & 31 & 0.0 & 100.0 \\
\hline $\mathrm{LDA}_{2}$ & N43 $02 \quad 42.8$ E2 1104.9 & 8 & 7 & 100.0 & 0.0 & 28 & 6 & 0.0 & 100.0 \\
\hline $\mathrm{LEU}_{1}$ & N42 5501.8 E3 0202.3 & 20 & 20 & 100.0 & 0.0 & & & & \\
\hline $\mathrm{LEU}_{2}$ & N42 5505.2 E3 0205.5 & 16 & 14 & 100.0 & 0.0 & & & & \\
\hline NAR & N43 1026.8 E2 5930.2 & 13 & 10 & 100.0 & 0.0 & & & & \\
\hline POR & N43 1837.2 E3 1915.3 & 20 & 8 & 12.5 & 87.5 & & & & \\
\hline POV & N42 3023.7 E3 0655.3 & 29 & 29 & 100.0 & 0.0 & 32 & 14 & 0.0 & 100.0 \\
\hline $\mathrm{PYM}_{1}$ & N43 1749.1 E2 3327.9 & 36 & 20 & 55.0 & 45.0 & 40 & 17 & 0.0 & 100.0 \\
\hline $\mathrm{PYM}_{2}$ & N43 1755.0 E2 3326.0 & 20 & 11 & 18.2 & 81.8 & & & & \\
\hline $\mathrm{PYM}_{3}$ & N43 1755.0 E2 3326.0 & 21 & 17 & 5.9 & 94.1 & & & & \\
\hline RXM & N43 1628.7 E2 3630.8 & 32 & 32 & 96.9 & 3.1 & 40 & 13 & 0.0 & 100.0 \\
\hline SPF & N42 49 17.1 E2 3008.0 & 7 & 5 & 0.0 & 100.0 & 28 & 12 & 0.0 & 100.0 \\
\hline THU & N42 3900.2 E2 4611.1 & 37 & 37 & 100.0 & 0.0 & 39 & 8 & 0.0 & 100.0 \\
\hline TRE & N42 $34 \quad 10.3$ E2 5104.8 & 36 & 34 & 100.0 & 0.0 & 22 & 9 & 0.0 & 100.0 \\
\hline VLZ & N43 1646.5 E2 2753.7 & 25 & 21 & 71.4 & 28.6 & 40 & 15 & 0.0 & 100.0 \\
\hline VMS & N43 1513.1 E2 2209.3 & 20 & 7 & 71.4 & 28.6 & & & & \\
\hline
\end{tabular}

All isolates collected at the beginning of the 2007 growing season originate from flag-shoot symptoms. 
(24:1) were then added and a centrifugation was performed at $3,700 \mathrm{rpm}$ at $4^{\circ} \mathrm{C}$ for $30 \mathrm{~min}$. The aqueous phase was collected and $200 \mu \mathrm{l}$ of isopropanol were added. DNA precipitation was performed at $-20^{\circ} \mathrm{C}$ for $2 \mathrm{~h}$. After centrifugation at $3,700 \mathrm{rpm}$ at $4^{\circ} \mathrm{C}$ for $20 \mathrm{~min}$, the pellet was rinsed with $500 \mu \mathrm{l}$ of $70 \%$ ethanol and centrifugated at 3,700 rpm for $10 \mathrm{~min}$. The DNA pellet was finally dissolved in $50 \mu 1$ of water.

Polymerase chain reactions (PCR) were performed in a $16.5 \mu \mathrm{l}$ volume containing $1.5 \mu \mathrm{l}$ of the stock genomic DNA solutions diluted $\times 3,1.5 \mu 1$ of $10 \mathrm{X}$ PCR Buffer (Eurogentec), $1.5 \mathrm{mM} \mathrm{MgCl} 2,0.5 \mathrm{mM}$ of each dNTP, $0.2 \mu \mathrm{M}$ of each primer (EnTub-F: 5'-GCGA GATCGTAAGCTTGACAC-3' and EnTub-R: 5'GGCACGAGGAACGTATTTGT-3') and 0.25 U Taq SilverStar DNA polymerase (Eurogentec). The PCR programme was performed as follows: a first denaturation step of $3 \mathrm{~min}$ at $96^{\circ} \mathrm{C}$, followed by 38 cycles of $40 \mathrm{~s}$ at $96^{\circ} \mathrm{C}, 55 \mathrm{~s}$ at $58^{\circ} \mathrm{C}, 55 \mathrm{~s}$ at $72^{\circ} \mathrm{C}$, and a final elongation step of $5 \mathrm{~min}$ at $72^{\circ} \mathrm{C}$. Cleaving reactions were realised in $10 \mu 1$ volume with $2 \mu 1$ of PCR product, $1 \mu 1$ of $10 \times-$ buffer no. 4 (BioLabs) and $1.5 \mathrm{U}$ of AccI enzyme (BioLabs) at a temperature of $37^{\circ} \mathrm{C}$ with an incubation period of $1.5 \mathrm{~h}$. Restriction fragments were visualised on $2 \%$ agarose after staining with ethidium bromide.

Disease assessment on leaves and clusters

At the end of the 2007 growing season, prior to the grape harvest (mid-September), the disease levels on leaves and clusters were visually estimated in 13 out of the 32 vineyards sampled at the beginning of the epidemic for genetic analysis. That estimation, based on the observation of five areas (composed at least of 100 vines) randomly distributed in the field, took into account incidence of diseased vines (i.e. an estimation of the percentage of diseased vines) and global symptom severity (i.e. an estimation of the percentage of leaf area infected), using the following category scale: $0=$ severity $<5 \%$ and incidence $0-5 \% ; 1=$ severity $<5 \%$ and incidence $5-20 \% ; 2=$ severity $<5 \%$ and incidence $20-50 \% ; 3=$ severity $<5 \%$ and incidence $>50 \%$; $4=$ severity $5-30 \%$ and incidence $>50 \%$; $5=$ severity $>30 \%$ and incidence $>50 \%$.

Statistical data analyses

The spatial autocorrelation structure for the frequency of genetic groups was analysed using the Spatial
Analysis in Macroecology v2.0 software (Rangel et al. 2006). Spatial autocorrelation measures the similarity between samples for a given variable as a function of spatial distance. The Moran's $I$ coefficient, which is the most commonly used coefficient in univariate autocorrelation analyses, was calculated for seven distance classes, each $15 \mathrm{~km}$ wide. Moran's $I$ compares the value of the variable at any one location with the value at all other locations. $I$ ranges from -1 to 1 , for maximum negative and positive autocorrelation, respectively. To estimate $P$-values, tests of significance were performed using 1,000 permutations. If no Moran's $I$ coefficients are significant, there is no spatial pattern in the data (i.e. absence of autocorrelation).

Correlations between the frequency of genetic groups and the altitude or the distance to the sea, and also between the initial frequency of group B isolates and the final disease levels on leaves or clusters, were carried out by Spearman's rank correlation rho using the statistical freeware $\mathrm{R}$, version 2.6.1 (R Development Core Team 2007).

\section{Results}

From the 769 lesions sampled at the beginning of the season, 659 (85.7\%) yielded a PCR amplicon of the $\beta$ tubulin gene; from the 484 lesions sampled at the end of the season, only 205 (42.4\%) did so. Genotyping failures could result either from an increased level in PCR inhibitors (as polyphenolic and polysaccharide compounds) in leaves along the epidemics (e.g. Tattersall et al. 2005), or from the sampling of inactive lesions towards the end of the epidemic. Both reasons may explain the higher success of genotyping on isolates collected at the start of the epidemics.

Among the 659 E. necator isolates collected at the beginning of the season from flag shoots, $440(67 \%)$ belonged to group A and 219 (33\%) to group B. This confirmed that both group A and group B isolates can over-winter as resting mycelium within dormant buds and lead to flag-shoot symptoms. The frequencies of the genetic groups per field varied greatly, from $100 \%$ group A (in ten fields) to $100 \%$ group B (in four fields). From the 18 fields showing a mix of A and B isolates, ten contained a majority of group A isolates and eight a majority of group B isolates (Table 1 and Fig. 1). 


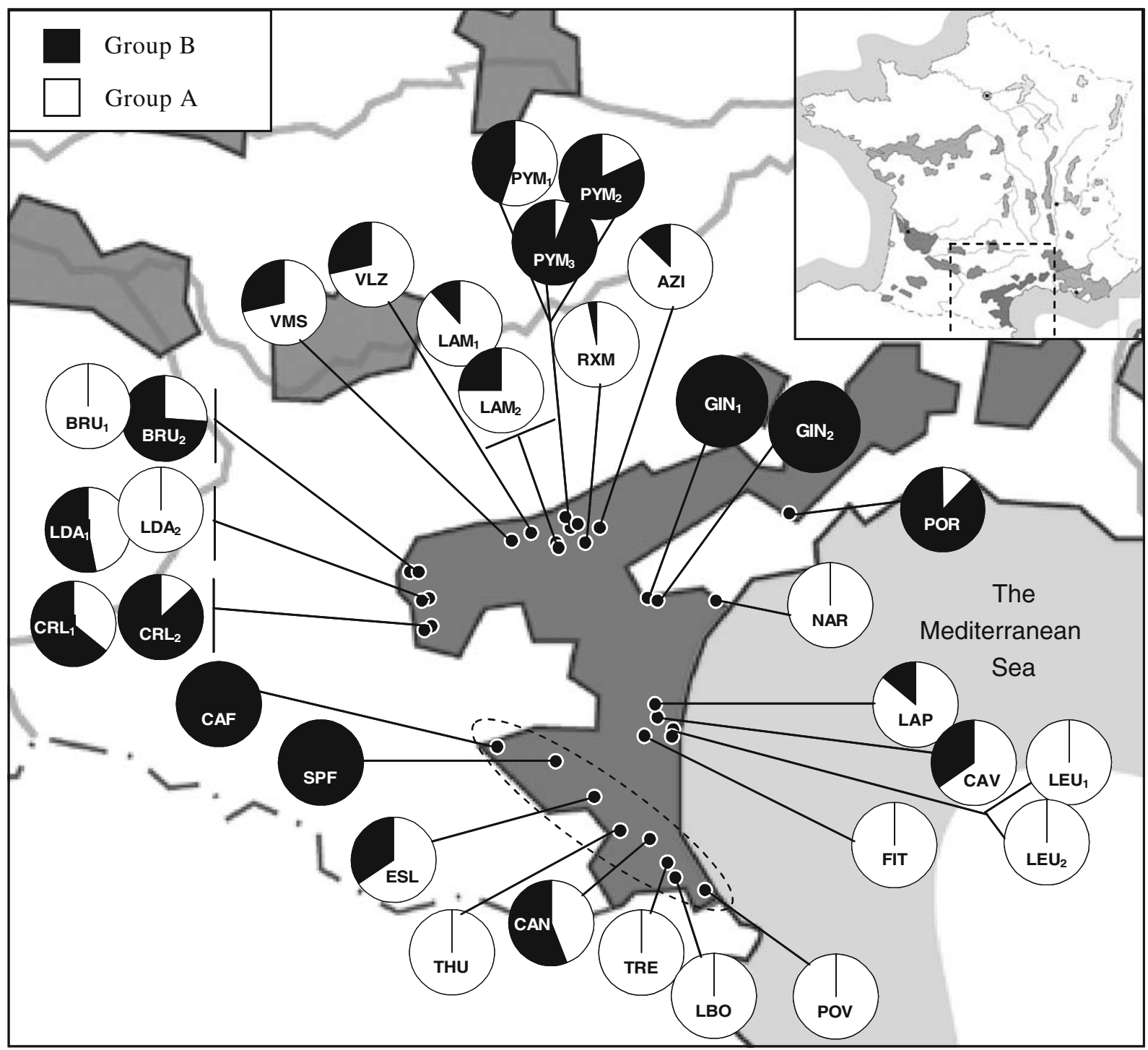

Fig. 1 Spatial distribution of the 32 fields sampled in the south of France, and frequency of Erysiphe necator isolates belonging to group A (white) and B (black) for each field. The dotted line shows the geographical position of the Agly's Valley

The autocorrelation analysis performed on our data did not allow the detection of the spatial structure of the two genetic groups, which appeared to be randomly distributed at the spatial scale of vineyards (Fig. 2). This is illustrated by the fact that neighbouring fields sometimes showed very different frequencies of E. necator genetic groups (Table 1 and Fig. 1). For instance, bru $_{1}$ and bru $_{2}$ which are $120 \mathrm{~m}$ away from one another, showed $100 \%$ and $26.1 \%$ of $\mathrm{A}$ isolates, respectively; similarly, the frequency of group A isolates in populations from vineyards $\mathrm{lda}_{1}$ and $1 \mathrm{da}_{2}$ (200 m away from each other) were $47.4 \%$ and $100 \%$, respectively. It is noteworthy that the eight vineyards situated along the Agly Valley (i.e. CAF at an altitude of $334 \mathrm{~m}$, SPF, ESL, THU, CAN, TRE, LBO and POV at an altitude of $32 \mathrm{~m}$ ) showed an altitudinal gradient related to the genetic structure of populations: E. necator isolates collected in the uppermost vineyards belonged to group $\mathrm{B}$, vineyards at an intermediate altitude showed a mix of A and B isolates, while populations from the lowest vineyards included exclusively group A isolates (Fig. 1). Nevertheless, neither the altitude nor the distance to the sea were significantly associated to genetic group frequency in the complete dataset (Fig. 3, Spearman's rank correlation $\mathrm{rho}=0.288, P=0.110$ for the altitude 


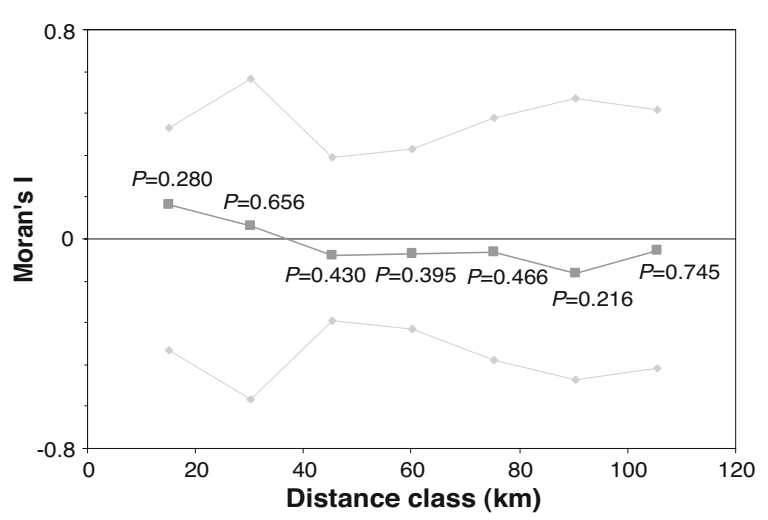

Fig. 2 Correlogram showing Moran's autocorrelation coefficient $I$ in relation to seven distance classes (class width $15 \mathrm{~km}$ ). Dotted curves showed the Max-Moran's I. P-values indicate each distance class

and Spearman's correlation rho $=0.305, P=0.090$ for the distance to the sea).

All isolates collected at the end of the growing season belonged to group $\mathrm{B}$, whatever the initial
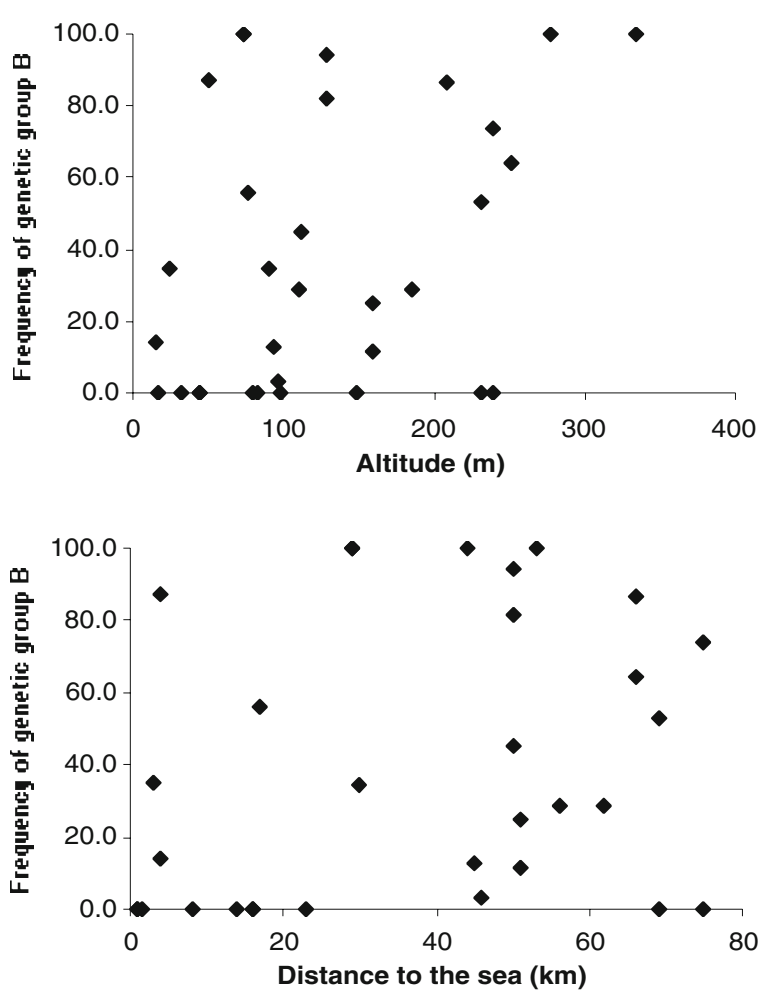

Fig. 3 Scatter-plots showing the relationship between frequency of E. necator genetic group B and altitude (at the top of the figure) or distance to the sea (at the bottom of the figure). Spearman's rank correlation rho $=0.288, P=0.110$ for altitude and Spearman's correlation rho $=0.305, P=0.090$ for distance to the sea frequencies of group $\mathrm{A}$; thus, even populations composed of $100 \% \mathrm{~A}$ at the start $\left(\mathrm{BRU}_{1}, \mathrm{FIT}\right.$, $\mathrm{LDA}_{2}, \mathrm{POV}$, THU and TRE) were $100 \% \mathrm{~B}$ at the end of the epidemic (Table 1 and Fig. 4).

A strong relationship was observed between the disease levels on leaves and clusters, estimated at the end of the growing season in 13 fields, and the initial frequency of genetic group B (Spearman's rank correlation rho $=0.905, P<0.001$ for damage on clusters and Spearman's correlation rho $=0.756, P=$ 0.003 for damage on leaves). Every vineyard from which only B isolates were detected at the onset of the epidemic had a high final severity of disease (disease score $>2$ ); whereas vineyards infected by E. necator populations including group A isolates (from 26.1\% to $100 \%$ ) had a low final disease severity (disease scores 0 or 1; Table 1 and Fig. 5).

\section{Discussion}

The spatial genetic analysis of flag-shoot symptoms sampled early in the season revealed the absence of aggregation of genetic groups at the vineyard scale in southern France. This result indicates that a genetic group was not more likely to occur in a vineyard if it was close to other fields including E. necator
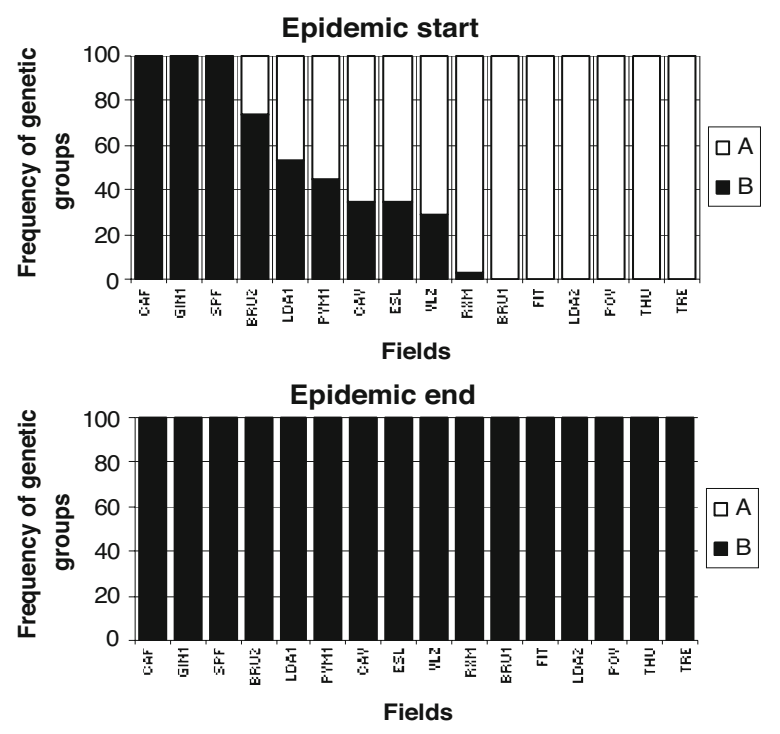

Fig. 4 Frequency of E. necator genetic groups, in the 16 fields sampled twice over the growing season, at the epidemic start (at the top of the figure) and at the epidemic end (at the bottom of the figure) 


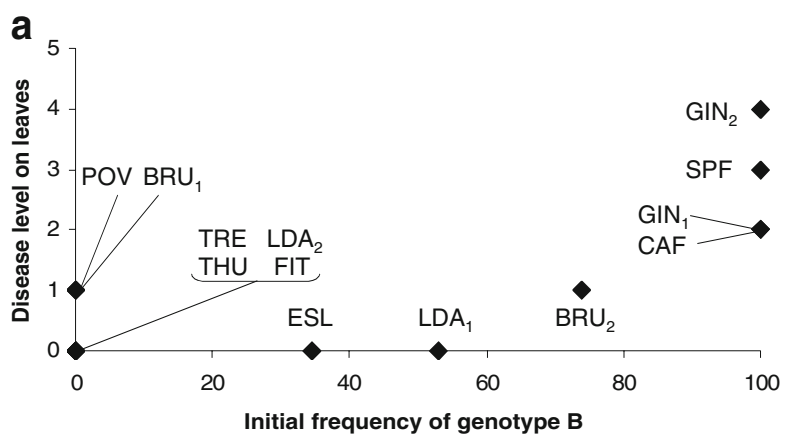

Fig. 5 Relationship between the powdery mildew levels on leaves (A) and clusters (B), estimated (using a 0-5 category scale that takes into account incidence of vine stocks diseased and global symptom severity) at the end of the growing season in 13 fields, and the initial frequency of genotype A, observed

populations of the same group. It is worth noting that our results do not exclude the possibility of withinfield aggregation of genetic groups. For instance, Cortesi et al. (2004, 2008) showed that flag-shoot symptoms were aggregated between consecutive years at the within-field scale, as a result of short distance dispersal of conidia from flag-shoots. At the spatial scale studied here, the two genetic groups of $E$. necator appeared randomly distributed, and neither the altitude nor the distance to the sea correlated with their spatial distribution. These results confirm previous data showing inter-vineyard heterogeneity in southern France on a smaller number of populations (Amrani and Corio-Costet 2006; Bouscaut and Corio-Costet 2007), and invalidate the hypothesis of a niche partitioning due to a geographic separation of the groups. Mechanisms underlying such spatial heterogeneity of genetic group distribution have not yet been identified: they could include effects of fungicide treatments, pruning modes, microbial antagonists, or local environmental conditions (micro-climate, soil) that could differentially favour genetic groups of $E$. necator. Since all samples were collected on $\mathrm{cv}$. Carignan, our results indicate that this pattern cannot be associated with an effect of the host cultivar. The spatial heterogeneity of genetic group proportions between vineyards could also reflect genetic drift operating through extinction-recolonisation dynamics characterising plant-pathogen metapopulations (Thrall and Burdon 1997; Laine and Hanski 2006). However, Cortesi et al. (2004, 2008) showed that flag-shoot symptoms are aggregated between consecutive years, suggesting that E. necator flag-shoot populations are

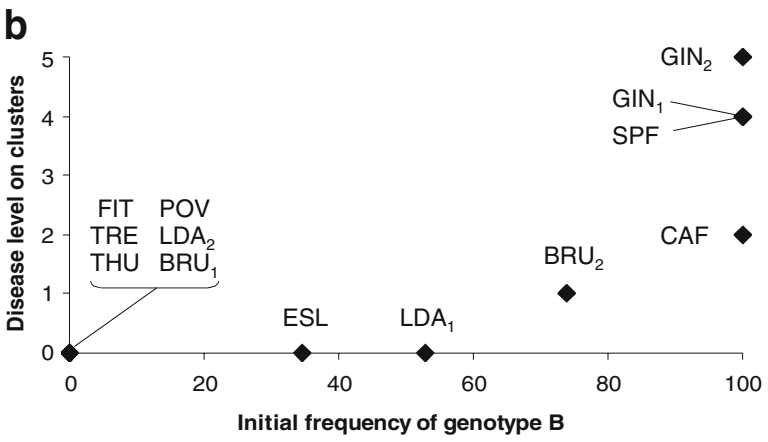

at the beginning of the growing season. Field names (threeletter code) are indicated on the graph. Spearman's rank correlation rho $=0.905, P<0.001$ for damage on clusters and Spearman's correlation rho $=0.756, P=0.003$ for damage on leaves

not characterised by strong extinction events. Since flag-shoot symptoms are aggregated from year to year, we can hypothesise that the within-field frequency of genetic groups estimated from flag-shoot symptoms could be stable over seasons.

While the spatial distribution of genetic groups of E. necator proved to be random, the temporal dynamics of groups was the same in all fields: the monitoring of 16 different fields showed that group A isolates were active only at the beginning of the growing season and disappeared during the course of the epidemic; by contrast group B isolates are active during the entire epidemic and were responsible for late infections. Our results support a temporal differentiation of niches of the two groups. The temporal succession of $E$. necator genetic groups has already been observed in France (Délye et al. 1999) and Italy (Miazzi et al. 2003), in 1998 and 1999, respectively. Although these studies were based on small sample sizes, these authors did not find any group A isolates after June in their samples. Since results obtained from different regions and different years have evidenced the decline of group A isolates during the course of the epidemics, our finding might not be due to environmental conditions specific for the 2007 growing season. Moreover, our results based on a set of 659 genotyped isolates collected from flagshoot symptoms, confirmed that both genetic groups are able to over-winter asexually in buds (Cortesi et al. 2005; Péros et al. 2005; Nuñez et al. 2006; Willocquet et al. 2007). Our data suggest that only $\mathrm{B}$ isolates could produce cleistothecia via sexual reproduction in vineyards, which takes place at the 
end of the growing season (Gadoury and Pearson 1988). Thus, at the beginning of the growing season, group A isolates ensure their over-wintering survival by colonising dormant buds for the next year shoots (Pearson and Gärtel 1985), whereas group B isolates may survive during winter both within dormant buds and via cleistothecia. The temporal isolation of genetic groups evidenced in our study is a potential mechanism which, by preventing recombination between $\mathrm{A}$ and $\mathrm{B}$ isolates, can explain the maintenance of the highly differentiated genetic structure in E. necator populations. Other studies suggest that recombination between groups of $E$. necator might occur: first, Miazzi et al. (2003) and Stummer and Scott (2003) showed that controlled sexual crosses between $\mathrm{A}$ and $\mathrm{B}$ genetic groups were viable and fertile; second, Cortesi et al. (2005) have shown the presence of both mating types at 1:1 ratios in natural populations of group A; third, Delmotte et al. (unpublished data) observed some discrepancies between different markers of E. necator genetic groups that suggested the presence at low frequency of recombinant isolates between A and B. Finally, we propose that the maintenance of the differentiation between the two genetic groups could result both from the temporal isolation highlighted here (prezygotic isolation), and possibly, from a lower fitness of recombinant isolates (postzygotic isolation). Determining more accurately the temporal dynamics of genetic groups of $E$. necator will require the collection of isolates over the course of an epidemic and a pluriannual monitoring of the same plots in order to also explore the dynamics of $E$. necator genetic groups over seasons.

Our data showed that damage due to E. necator on leaves and clusters was less important in commercial vineyards where epidemics started with populations including A isolates than in vineyards showing flagshoot symptoms caused by group B isolates. The strong association between disease severity at the end of the growing season and the initial composition of the populations raises new questions with both practical and theoretical interests. A hypothesis to explain the association between the initial frequency of A and B groups and damage on clusters at harvest could lie in a difference in aggressiveness on berries between E. necator genetic groups. Because the susceptibility period of clusters is restricted to about two weeks after bloom (Gadoury et al. 2003), and assuming a higher aggressiveness of B isolates on berries, the genetic composition of E. necator populations during the susceptibility period of clusters could be the major factor driving damage on berries at harvest. Thus, an initial attack by a population mainly composed of group B isolates (aggressive on berries) would cause severe damage at harvest; conversely, if group B isolates increase in frequency only later (i.e., when the ontogenic, or age-related resistance of clusters is active) then the epidemic will cause little or no damage at harvest. Such a difference in aggressiveness was observed between two genetically distinct groups of the plant pathogen Gaeumannomyces graminis var. tritici (Ggt). Aggressiveness (defined as the disease severity that reflects the extension of root necrosis) of group G2 (38\%) was significantly greater than that of group G1 (29.5\%) in controlled laboratory tests (Lebreton et al. 2004). Moreover, a linear relationship between G2 frequency within Ggt populations and disease severity at stem elongation was measured during three cropping seasons (Lebreton et al. 2007). Interestingly, the ontogenic resistance of leaves (Doster and Schnathorst 1985) is less limited in time because of the continuous growth of the vine. This might explain why the association between the frequency of genetic groups and disease levels was slightly stronger on clusters than on leaves. In order to test our hypothesis, further experiments are needed to investigate the aggressiveness of each E. necator genetic group on leaves and berries. Moreover, because our observations were based on a limited number of vineyards/populations and did not take into account chemical protection, it will be necessary to follow the epidemic development on leaves and clusters in crops showing different frequencies of genetic E. necator groups and with standardised farming methods. A landscape genetic approach will help to determine ecological factors involved in the temporal and spatial genetic variability of E. necator populations. The identification of factors favouring one group over another will provide useful information for an integrated crop management with limited fungicide use.

Acknowledgements We are very grateful to L. Willocquet, D. Andrivon, M.L. Desprez-Lousteau, A. Calonnec and two anonymous referees for valuable comments on previous versions of this paper. This work was carried out within the frame of a research project (no. 20061202001) supported by the Région Aquitaine. 


\section{References}

Amarasekare, P. (2003). Competitive coexistence in spatially structured environments: A synthesis. Ecology Letters, 6, 1109-1122.

Amrani, L., \& Corio-Costet, M. F. (2006). A single nucleotide polymorphism in the beta-tubulin gene distinguishing two genotypes of Erysiphe necator expressing different symptoms on grapevine. Plant Pathology, 55, 505512.

Baudoin, A., Olaya, G., Delmotte, F., Colcol, J. F., \& Sierotzki, H. (2008). QoI resistance of Plasmopara viticola and Erysiphe necator in the mid-Atlantic United States. Plant Health Progress. doi:10.1094/PHP-2008-0211-02-RS.

Bouscaut, J., \& Corio-Costet, M. F. (2007). Detection of a specific transposon in Erysiphe necator from grapevines in France. Journal of Phytopathology, 155, 81-383.

Chesson, P. (2000). Mechanisms of maintenance of species diversity. Annual Review of Ecology and Systematics, 31, 343-366.

Cortesi, P., Mazzoleni, A., Pizzatti, C., \& Milgroom, M. G. (2005). Genetic similarity of flag shoot and ascospore subpopulations of Erysiphe necator in Italy. Applied and Environmental Microbiology, 71, 7788-7791.

Cortesi, P., Ottaviani, M. P., \& Milgroom, M. G. (2004). Spatial and genetic analysis of flag shoot subpopulation of Erysiphe necator in Italy. Phytopathology, 94, 544-550.

Cortesi, P., Pizzatti, C., Bertocchi, D., \& Milgroom, M. G. (2008). Persistence and spatial autocorrelation of clones of Erysiphe necator overwintering as mycelium in dormant buds in an isolated vineyard in Northern Italy. Phytopathology, 98, 148-152.

Délye, C., \& Corio-Costet, M. F. (1998). Origin of primary infections of grape by Uncinula necator: RAPD analysis discriminates two biotypes. Mycological Research, 102, 283-288.

Délye, C., Laigret, F., \& Corio-Costet, M. F. (1997). RAPD analysis provides insight into the biology and epidemiology of Uncinula necator. Phytopathology, 87, 670-677.

Délye, C., Ronchi, V., Laigret, F., \& Corio-Costet, M. F. (1999). Nested allele-specific PCR primers distinguish genetic groups of Uncinula necator. Applied and Environmental Microbiology, 65, 3950-3954.

Doster, M. A., \& Schnathorst, W. C. (1985). Effects of leaf maturity and cultivar resistance on development of the powdery mildew fungus on grapevines. Phytopathology, $75,318-321$.

Evans, K. J., Whisson, D. L., Stummer, B. E., \& Scott, E. S. (1997). DNA markers identify variation in Australian populations of Uncinula necator. Mycological Research, 101, 923-932.

Fitt, B. D. L., Huang, Y. J., van den Bosch, F., \& West, J. S. (2006). Coexistence of related pathogen species on arable crops in space and time. Annual Review of Phytopathology, 44, 163-182.

Fournier, E., Giraud, T., Albertini, C., \& Brygoo, Y. (2005). Partition of the Botrytis cinerea complex in France using multiple gene genealogies. Mycologia, 97, 1251-1267.

Gadoury, D. M., \& Pearson, R. C. (1988). Initiation, development, dispersal and survival of cleistothecia of Uncinula necator in New York vineyards. Phytopathology, 78, 1413-1421.

Gadoury, D. M., Seem, R. C., Ficke, A., \& Wilcox, W. F. (2003). Ontogenic resistance to powdery mildew in grape berries. Phytopathology, 93, 547-555.

Gausse, G. F. (1934). The struggle for existence. Baltimore: Williams and Wilkins.

Laine, A. L., \& Hanski, I. (2006). Large-scale spatial dynamics of a specialist plant pathogen in a landscape. Journal of Ecology, 94, 217-226.

Lebreton, L., Gosme, M., Lucas, P., Guillerm-Erckelboudt, A. Y., \& Sarniguet, A. (2007). Linear relationship between Gaeumannomyces graminis var. tritici (Ggt) genotypic frequencies and disease severity on wheat roots in the field. Environmental Microbiology, 9, 492499.

Lebreton, L., Lucas, P., Dugas, F., Guillerm, A.-Y., Schoeny, A., \& Sarniguet, A. (2004). Changes in population structure of the soilborne fungus Gaeumannomyces graminis var. tritici during continuous wheat cropping. Environmental Microbiology, 6, 1174-1185.

Manel, S., Schwartz, M. K., Luikart, G., \& Taberlet, P. (2003). Landscape genetics: combining landscape ecology and population genetics. Trends in Ecology \& Evolution, 18, 189-197.

Miazzi, M., Hajjeh, H., \& Faretra, F. (2003). Observations on the population biology of the grape powdery mildew fungus Uncinula necator. Journal of Plant Pathology, 85, 123-129.

Nuñez, Y., Gallego, J., Ponz, F., \& Raposo, R. (2006). Analysis of population structure of Erysiphe necator using AFLP markers. Plant Pathology, 55, 650-656.

Pearson, R. C., \& Gärtel, W. (1985). Occurrence of hyphae of Uncinula necator in buds of grapevine. Plant Disease, 69, 149-151.

Péros, J. P., Troulet, C., Guerriero, M., Michel-Romiti, C., \& Notteghem, J. L. (2005). Genetic variation and population structure of the grape powdery mildew fungus, Erysiphe necator, in southern France. European Journal of Plant Pathology, 113, 407-416.

Plantegenest, M., Le May, C., \& Fabre, F. (2007). Landscape epidemiology of plant diseases. Journal of the Royal Society Interface, 4, 963-972.

Rangel, T. F. L. V. B., Diniz-Filho, J. A. F., \& Bini, L. M. (2006). Towards an integrated computational tool for spatial analysis in macroecology and biogeography. Global Ecology and Biogeography, 15, 321-327.

Seko, Y., Bolay, A., Kiss, L., Heluta, V., Grigaliunaite, B., \& Takamatsu, S. (2008). Molecular evidence in support of recent migration of a powdery mildew fungus on Syringa spp. Into Europe from East Asia. Plant Pathology, 57, 243-250, doi:10.1111/j.1365-3059.2007. 01775.x.

Stummer, B. E., \& Scott, E. S. (2003). Detection of novel genotypes in progeny from a controlled cross between isolates of Uncinula necator belonging to distinct phonetic groups. Australian Plant Pathology, 32, 213218.

Tattersall, E. A. R., Ergul, A., Alkayal, F., DeLuc, L., Cushman, J. C., \& Cramer, G. R. (2005). Comparison of methods for isolating high-quality RNA from leaves of 
grapevine (Vitis vinifera L.). American Journal of Enology and Viticulture, 56, 400-406.

Thrall, P. H., \& Burdon, J. J. (1997). Host-pathogen dynamics in a metapopulation context: the ecological and evolutionary consequences of being spatial. Journal of Ecology, 85, 743-753.

Williams, R. H., \& Fitt, B. D. L. (1999). Differentiating A and B groups of Leptosphaeria maculans, causal agent of stem canker (blackleg) of oilseed rape. Plant Pathology, 48, 161-175.
Willocquet, L., Cartolaro, P., Jolivet, J., Richard-Cervera, S., \& Delmotte, F. (2007). Relationships between genetic group, symptom type, and epidemiological features in Erysiphe necator, the causal agent of grape powdery mildew. Phytopathology, 97(Suppl.), S123.

Wilson, M., \& Lindow, S. E. (1994). Coexistence among epiphytic bacterial populations mediated through nutritional resource partitioning. Applied and Environmental Microbiology, 60, 4468-4477. 